2. Bonney, R. J.: Adult liver parenchymal cells in primary cultures. In Vitro, I0: $130(1974)$

3. Chen, P. S., Jr., Toribara, T. Y.. and Warner, H.: Microdetermination of phosphorus. Anal. Chem., 28: 1756 (1956).

4. Erickson, R. P., Gluecksohn-Waelsch, S., and Cori, C. F.: Glucose-6-phosphatase deficiency caused by radiation induced alleles at the albino locus in the mouse. Proc. Natl. Acad. Sci., 59: 437 (1968).

5. Field, J. B., Epstein, S., and Egan, T.: Studies in glycogen storage disease: Intestinal glucose-6-phosphatase activity in patients with Von Gierke's disease and their parents. J. Clin. Invest., 44: 1240 (1965).

6. Gerbie, A. B., Malancon. S. B., Ryan, C., and Nadler, H.: Cultivated epithelial-like cells and fibroblasts from amniotic fluid. Amer. J. Obstet. Gynecol.. 114: 314 (1972)

7. Greene, H. L., Slonim, A. F., ONeill, J. A., and Barr, I. M.: Continuous nocturnal intragastric feeding for the management of type I glycogen storage disease. N. Engl. J. Med., 294: 423 (1976).

8. Granner, D. K., and Tomkins, G. M.: Tyrosine aminotransferase. In: H Tabor and C. W. Tabor: Methods in Enzymology, Vol. 17, p. 533 (Academic Press, New York, 1970 )

9. Heukels-Dully, M. J., and Niermeijer, M. F.: Variation in lysosomal enzyme activity during growth in culture of human fibroblasts and amniotic fluid cells. Exp. Cell. Res., 97: 304 (1976)

10. Kaighn, E. M., and Prince, A. M.: Production of albumin and other serum proteins by clonal cultures of normal human liver. Proc. Natl. Acad. Sci. U.S.A., 68: $2396(197 !)$

11. Malancon, S. B., Lee, S. Y., and Nadler, H.: Histidase activity in cultivated human amniotic fluid cells. Science, 173: 627 (1971).

12. Milunsky, A. N.: Current concepts: Prenatal diagnosis of genetic disorders. N. Engl J. Med 295: 377 (1976).

13. Negishi, H., Morishita, Y., Kodama, S., and Matsuo, T.: Platelet glucose-6phosphatase activity in patients with Von Gierke's Disease. Clin. Chim Actit. 53: 175 (1974).
14. Negishi, H., and Benke, P.: In preparation (1977).

15. Nemeth, A. M.: Glucose-6-phosphatase in the liver of the fetal guinea pig. J. Biol. Chem., 208: 773 (1954)

16. Novak, M., Hahn, P., Pardo, V., Monkus, E., and Alzamora, D.: The effect of carnitine on respiration of mitochondria obtained from newhorn and adult subcutaneous white adipose tissue. Int. J. Biochem., 5: 223 (1974).

17. Russell, J. D., Cori, C. F., and Gluecksohn-Waelsch, S.: Further studies on the $x$-ray induced genetic loss of glucose-6-phosphatase in liver and kidney of mice. Fed. Eur. Biochem. Soc. Symp.. 19: 315 (1969).

18. Sandstrom, B.: Studies on liver cells cultured in vitro. Exp. Cell. Res., 37: 552 (1965).

19. Schwartz, A. L., Neils, C. R., and Rall. T. W.: Effect of dibutyryl cyclic AMP on glucose-6-phosphatase activity in human fetal explants. Biochim. Biophys. Acta, 343: 500 (1974).

20. Williams, G. M., Weisburger, E. K., and Weisburger, J. H.: Isolation and long-term cell culture of epithelial-like cells from rat liver. Exp. Cell Res., 69: $106(1971)$

21. Young, E., Willcox, P., Whitfield, A. E., and Patrick, A. E.: Variability of acid hydrolase activity in cultured skin fibroblasts and amniotic fluid cells. J. Med. Genet., 12: $22+$ (1975).

22. Dr. H. Negishi is a postdoctoral fellow of the Mailman Foundation, the Biegetson Foundation, and Medical-Dental Wives of Palm Beach County. The present address of Dr. H. Negishi is: Department of Pediatrics, Kobe University School of Medicine, Kusunoki-cho 7 chome Ikuta-ku, Kobe (Japan).

23. This research was supported by a Basil O'Connor Grant from the National Foundation-March of Dimes.

24. Requests for reprints should be addressed to: P. J. Benke, M.D., Mailman Center, University of Miami Medical School, Miami, Fla. 33152 (USA)

25. Received for publication October 18, 1976

26. Accepted for publication February 3. 1977.
DNA

hyperbilirubinemia neonate nucleotide bodies peroxidase staining phototherapy

\title{
Peroxidase Technique for the Detection of Photochemical Lesions in Intracellular Deoxyribonucleic Acid
}

\author{
REGINA M. SANTELLA, HERBERT S. ROSENKRANZ, SHARI BREM, BEVERLY W. LUBIT, \\ BERNARD F. ERLANGER. AND WILLIAM T. SPECK ${ }^{(1+1)}$
}

Departments of Microbiology and Pediatrics, College of Physicians and Surgeons, Columbia University, New York. New York, USA

\section{Summary}

The widespread use of phototherapy for the prevention and treatment of neonatal hyperbilirubinemia has generated some concern as physiologic substances other than bilirubin may be photoactivated. Little information is available on the long term toxicity of these photodecomposition products. Recent observations of the in vitro DNA-modifying activity of phototherapy lights has encouraged us to develop laboratory procedures which can identify and quantitate these light-induced alterations. The purpose of the present study was to develop a technique capable of detecting photochemical changes in the genetic material of human cells in tissue culture. The results demonstrate that the antinucleoside peroxidase staining procedure is capable of detecting changes in the DNA of human cells exposed to physiologic (riboflavin) and nonphysiologic (methylene blue) photosensitizing agents in the presence of light with a fluence rate $(450$ $\mathrm{nm})$ of $141 \mu \mathrm{W} \cdot \mathrm{cm}^{2}$.

\section{Speculation}

In view of the known relationship between the ability of a number of environmental agents to modify DNA on the one hand and their potential to induce mutations and cancer on the other, the present study, which documents the DNA-modifying potential of phototherapy, raises questions regarding the safety of this therapeutic maneuver. The further development of techniques described here to identify and quantitate photochemical alterations in the genetic material of irradiated infants would enable us to intelligently define the risk-benefit ratio of phototherapy and to identify an at risk population for long term follow-up studies.

The effects of environmental agents on child health is a subject of considerable interest at the present time (1). Of special concern are the long term effects of such agents and more specifically their carcinogenic, mutagenic, and teratogenic po- 
tential which is derived in part from the ability of these agents to modify intracellular DNA. Our laboratory has been systematically evaluating the DNA-modifying potential of an environmental agent commonly utilized in clinical pediatrics for the treatment and prevention of neonatal hyperbilirubinemia-high intensity illumination with visible light or phototherapy. Investigations thus far suggest that the DNA-modifying potential of phototherapy is dependent upon the generation of singlet oxygen and the subsequent oxidation of the guanine moicties of the DNA molecule $(8,9)$. Because of the frequent exposure of jaundiced infants to this therapeutic maneuver, we have been interested in developing laboratory procedures which can be used clinically to identify and quantitate alterations in the genetic material of irradiated infants. The purpose of the present communication is to describe a system in which the photooxidation of guanine in living human cells in tissue culture can be detected. The procedure described utilizes antibodies which are specific for free cytosine and have been used to detect free base residues in human cells exposed to physiologic (riboflavin) and nonphysiologic (methylene blue) photosensitizing agents.

\section{MATERIALS AND METHODS}

Riboflavin was purchased from Sigma Company and methylene blue from Allied Chemical Company.

\section{PREPARATION OF ANTI-C ANTIBODY}

The preparation of nucleoside conjugates (2) and the procedure for purification of rabbit anti-C antibody has been described previously (10). Peroxidase labeled sheep anti-rabbit antibody was prepared by the method of Lubit et al. (5).

\section{PREPARATION OF CELLS}

Human (KB) cells were grown in monolayers on chambered slides (Miles Laboratories) in Eagle's medium containing calf

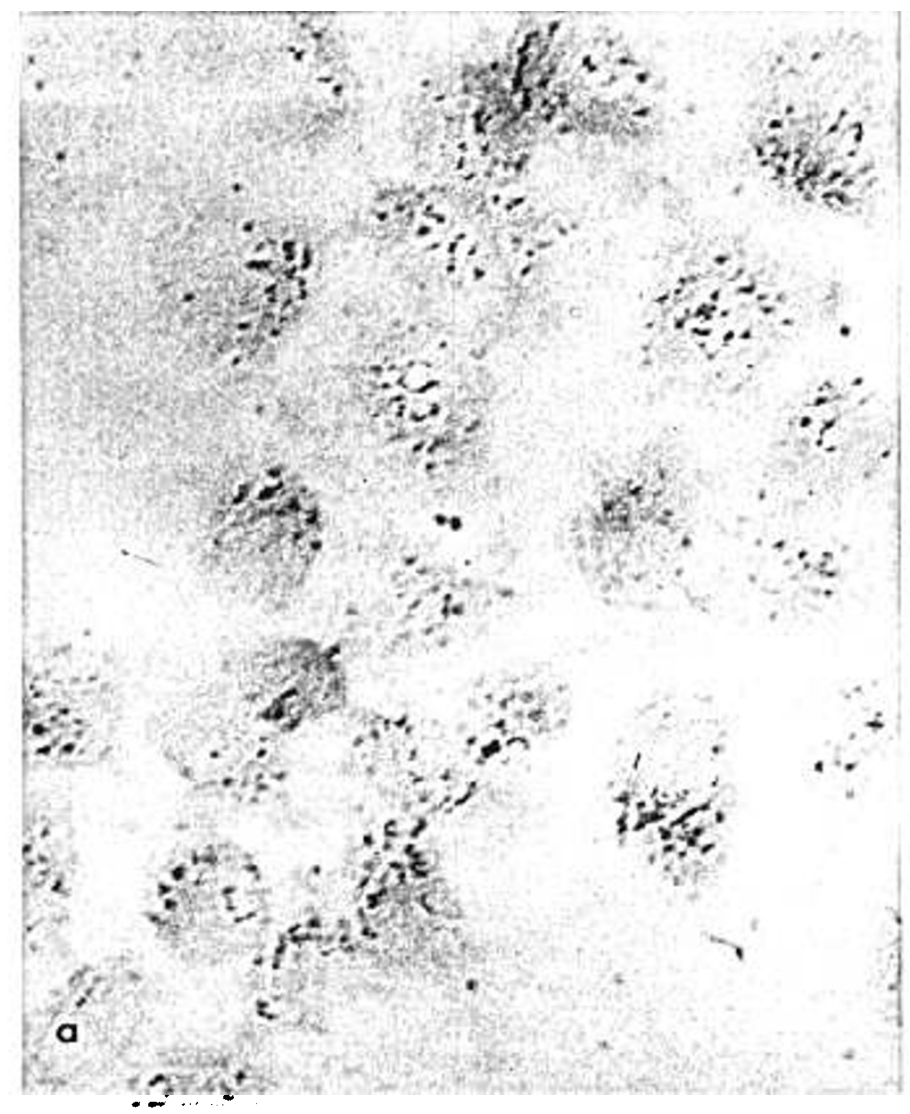

serum (10\%) and glutamine. The cells were washed with phosphate-buffered saline containing $5 \%$ dextrose (D, PBS) and exposed to 25 or $50 \mu \mathrm{g}$ riboflavin/ $\mathrm{ml}$ or $10 \mu \mathrm{g}$ methylene blue/ $\mathrm{ml}$ in $\mathrm{D}_{5}$ PBS. After incubation in the dark at $37^{\circ}$ for $1 \mathrm{hr}$ the cells were illuminated under a standard phototherapy unit (Dura Test Vita Lite). The unit was protected from direct sunlight and air-cooled to maintain the cultures at $23^{\circ}$. The sample distance from the light source was adjusted to maintain a fluence rate $(450 \mathrm{~nm})$ of $1+1 \mu \mathrm{W} \mathrm{cm}^{2}$. All photometric measurements were made with the IL600 A photometer coupled to the IL600 photodensitometer manufactured by International Light. Inc. After illumination the cells were fixed and stained as previously described (5).

\section{RESULTS}

Examination of the cells treated with anti-C antibody revealed peroxidase statining only in the nuclei of those cells illuminated in the presence of riboflavin or methylene blue. The intensity of staining reflects the amount of free cytosine residues (Fig. I $a$ and $2)$. Illumination of the cells in the absence of photosensitizers or cells exposed to methylene blue or riboflavin in the dark failed to demonstrate significant staining (Fig. 1b). The specificity of the photochemical reaction was confirmed by demonstrating minimal peroxidase-positive material in cells treated with anti-T. Under these conditions less than $10 \%$ of the cells are killed as shown by trypan blue staining.

\section{DISCUSSION}

Large numbers of newborn infants are systematically exposed to an environmental agent with DNA-modifying activity. No procedure is presently available which ean be used clinically to accurately identify and quantitate alterations in the genetic material of infants receiving phototherapy. Many of the technicues

Fig. 1. a: peroxidase-positive staining in nuclei of cells grown in monolayers with $50 \mu \mathrm{g} / \mathrm{ml}$ riboflavin and 1 hr of light as described in " $\mathrm{Naterials}$ and Methods." $b$ : control cells treated with $50 \mu \mathrm{g} / \mathrm{ml}$ riboflavin in the dark. 


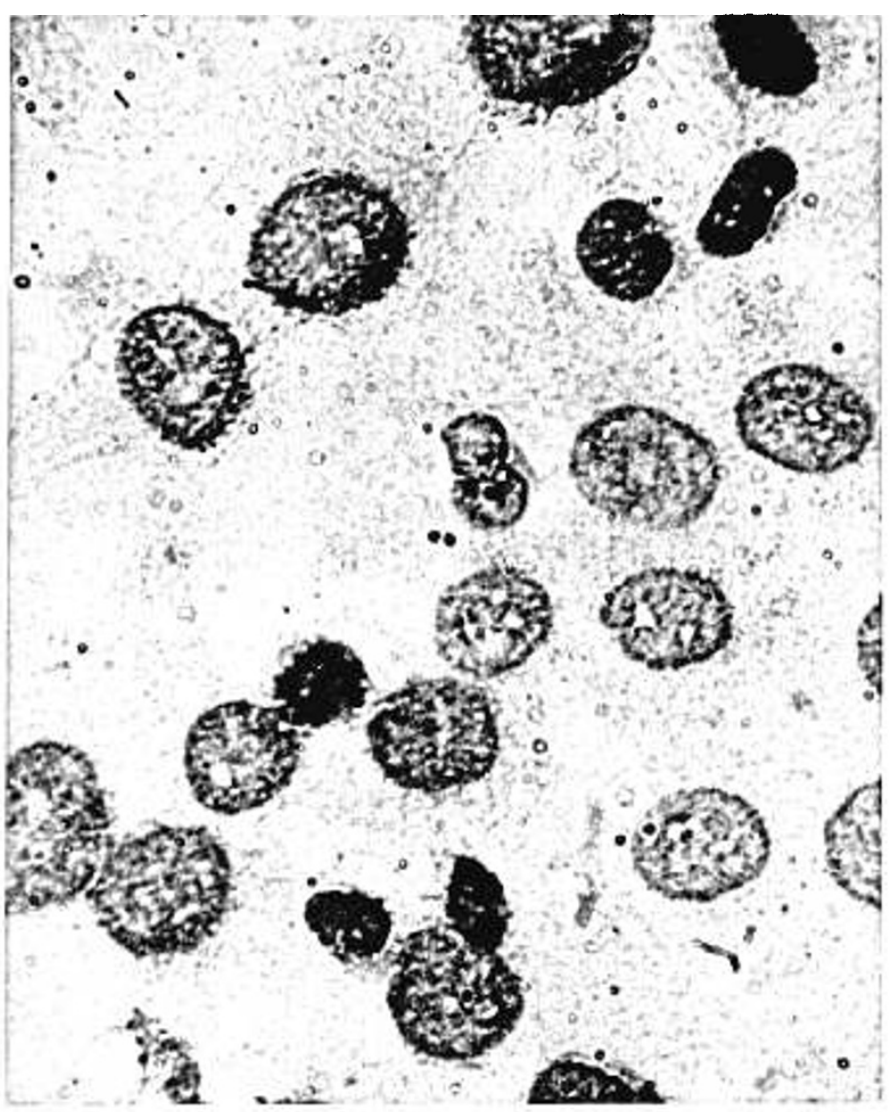

Fig. 2. Peroxidase-positive staining in nuclei of eells grown in monoayers treated with $10 \mu \mathrm{g} / \mathrm{ml}$ methylene blue and $1 \mathrm{hr}$ of light as lescribed in "Naterials and Nethods."

Atilized to study the effects of photosensitizing agents on DNA in itro are complex and do not lend themselves to routine use in a linical sctting.

Antinucleoside antibodies have been developed which specifially react with the purine and pyrimidine group of the immunizng antigen. These antibodies, which react with free base resiJues, are capable of reacting with single stranded, denatured, or artially denatured DNA. The immunochemical specificities of hese reactions have been shown by complement fixation, pre:ipitation, and radioimmunological techniques $(3,6)$. Photosenitizing agents like methylene blue, in the presenee of oxygen and visible light. generate singlet oxygen which selectively deitroys the guanine moicty of the DNA molecule (7). Garro et al. 3 ) and others (11) documented the methylene blue photodegralation of guanosine in isolated DNA using cytosine-specific Intinucleoside antibody which reacted with the unpaired cytoine residues in the treated DNA. We have previously docunented the light-activated methylene blue induced photooxidaion of guanosine in the DNA of living human cells utilizing fluorescein-tagged antibody specific for the unpaired cytosine residues of the intracellular DNA (4). Because of occasional difficulties in recognizing fluorescence and the lack of permanenee in the treated preparations, we felt that the fluorescent technique was unsatisfactory for routine clinical use.

The peroxidase staining procedure described in this report provides a permanent record which can be easily interpreted by a laboratory technician. Utilizing this procedure we were able to document the methylene blue-induced photooxidation of the guanosine moiety of the DNA in human cells in tissue culture. Moreover, the sime technique was used to detect free cytosine residues in human cells exposed to phototherapy lights in the presenes of low concentrations of riboflavin. The presence of these unpaired bases confirms our earlier investigations on the effect of light-activated riboflavin, on isolated DNA and the DNA of human cells in tissue culture ( 8 ). The present report underscores our earlier recommendations that riboflavin supplementation as an adjunct to phototherapy for hyperbilirubinemia requires thorough evaluation before its use can become routine (8).

The case of preparation and interpretation of the antinucleoside-peroxidase staining procedure encourages us to further modify this technique to facilitate its use in clinical pediatrics for identifying and quantitating alterations in the genetic material of infants exposed to high intensity illumination or phototherapy.

\section{RI:IIEREN(I:S ANI) NOTES}

1. Committec on Environmental Hazards: The susceptibility of the fetus and child to chemical pollutants. Pediatrics (Suppl. 11). 53: (1974).

2. Erlanger, B. F., and Beiser, S. M.: Antibodies specific for ribonuckeosides and ribonucleotides and their reaction with DNA. Proc. Natl. Acad. Sci. U.S.A.. 52: $68(1964)$

3. Carro, A. J., Vilanger. B. F., and Beiser, S. M.: Specificity in the reaction between anti-pyrimidine nucleoside antibodies and DNA in nucleic acids. In: O.J. Plescia and W. Braun:In: Immunology

4. Ciutter, B., Nishioka, Y., Speck, W. T., et al: Immunofluorescence for the detection of photechemical lesions in intracellular DNA. Fxp. (ell Res. 10): $413(1970)$

5. I.ubit. B. W., Schreck. R. R., Miller, (). J., and Erlanger, B. F.: Human chromosome structure as revealed by an immunoperoxidase staining procedure. lixp. Cell Res., 89: 426 (1974).

6. Senitzer. D.. Erlanger, B. F., and Beiser, S. M.: Binding of antinucleoside antibody to DNA. Immunochemistry. II: 321 (1974).

7. Simon, M. I., and Van Vunikis, H.: The photodynamic reaction of methylene blue with deoxyrihonucleic acid. J. Mol. Biol. 4 : 488 (1962).

8. Speck, IV. T., Cheng, C. C., and Rosenkranz., H. S.: In vitro studies of effects of light and riboflavin on DNA and Hel at celts. Pediat. Res.. 9: 150 (1975)

9. Speck, W. T., and Rosenkranz, H. S.: The bilirubin-induced photodegradation of DNA. Pediat. Res., 9: 70.3 (1975)

10. Szafran, H., Beiser, S. M., and Erlanger, B. F.: The use of egg alhumin conjugates for the purification of antibody. J. Immunol., 103: 1157 (1969).

11. Waskell, C. A.. Sastry, K. S., and Gorden, M. P.: Studies on the photosensitized breakdow of guanosine by methylene blue. Biochem. Biophys. Acta. 129: 49 (1966).

12. The present address of Dr. H. S. Rosenkranz is: Department of Microbiology, New York Medical College, Valhalla. N.Y. I0595 (USA).

13. This rescarch was supported by the George $C$. Smith Fund and the National Institute of Envirenmental Health Sciences Grant No. 1 RO1 1:S-()1293-1)1.

14. Requests for reprints should be addressed to: W. T. Speck, M1.D., Department of Pediatries. Case Western Reserve University, Cleveland, Ohio $4+1116$ (USA).

15. Received for publication November 8,1976

16. Accepted for publication January 27, 1977. 